University of Chicago Law School

Chicago Unbound

Public Law and Legal Theory Working Papers

Working Papers

2008

\title{
The Heart Has Its Reasons: Examining the Strange Persistence of the American Death Penalty
}

Susan A. Bandes

Follow this and additional works at: https://chicagounbound.uchicago.edu/public_law_and_legal_theory

Part of the Law Commons

Chicago Unbound includes both works in progress and final versions of articles. Please be aware that a more recent version of this article may be available on Chicago Unbound, SSRN or elsewhere.

\section{Recommended Citation}

Susan A. Bandes, "The Heart Has Its Reasons: Examining the Strange Persistence of the American Death Penalty" (University of Chicago Public Law \& Legal Theory Working Paper No. 200, 2008).

This Working Paper is brought to you for free and open access by the Working Papers at Chicago Unbound. It has been accepted for inclusion in Public Law and Legal Theory Working Papers by an authorized administrator of Chicago Unbound. For more information, please contact unbound@law.uchicago.edu. 


\section{CHICAGO}

John M. Olin LAW \& ECONOMics WORKING PAPER No. 378

(2D SERIES)

Public LaW and Legal Theory Working Paper No. 200

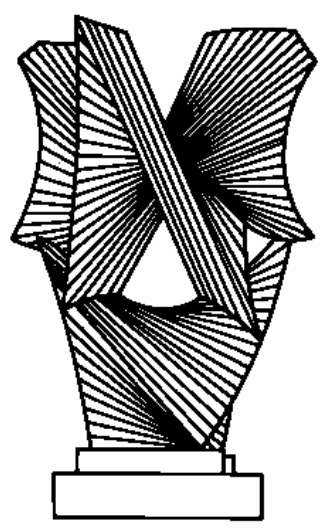

\section{THE HEART HAS ITS REASONS: \\ EXAMINING THE STRANGE PERSISTENCE OF THE AMERICAN DEATH PENALTY \\ Susan Bandes}

\section{THE LAW SCHOOL THE UNIVERSITY OF CHICAGO}

January 2008

This paper can be downloaded without charge at the John M. Olin Program in Law and Economics Working Paper Series: http://www.law.uchicago.edu/Lawecon/index.html and at the Public Law and Legal Theory Working Paper Series:

http://www.law.uchicago.edu/academics/publiclaw/index.html and The Social Science Research Network Electronic Paper Collection:

http://ssrn.com/abstract_id=1019615 


\title{
The Heart Has Its Reasons: Examining the Strange Persistence of the American Death Penalty
}

Forthcoming in Volume 42 of Studies in Law, Politics and Society (2008).

\begin{abstract}
:
The debate about the future of the death penalty often focuses on whether its supporters are animated by instrumental or expressive values, and if the latter, what values the penalty does in fact express, where those values originated, and how deeply entrenched they are. In this article I argue that a more explicit recognition of the emotional sources of support for and opposition to the death penalty will have salutary consequences for the clarity of the debate. The focus on emotional variables reveals that the demarcation between instrumental and expressive values is porous; both types of values are informed (or uninformed) by fear, outrage, compassion, selective empathy and other emotional attitudes. More fundamentally, though history, culture and politics are essential aspects of the discussion, the resilience of the death penalty cannot be adequately understood when the affect is stripped from explanations for its support. Ultimately, the death penalty will not die without a societal change of heart.
\end{abstract}

\author{
Susan Bandes \\ Distinguished Research Professor \\ DePaul University College of Law \\ Visiting Professor \\ University of Chicago Law School 2007-08 \\ 1111 E. 60 $^{\text {th }}$ Street \\ Chicago, IL 60637 \\ (773) 7020953 \\ sbandes@depaul.edu
}




\section{The Heart Has Its Reasons: Examining the Strange Persistence of the American Death Penalty}

\section{Susan Bandes*}

Before we can predict the fate of the death penalty, we need to understand why capital punishment has persisted for so long in the United States. Why have we continued to execute people into the twenty-first century, despite evidence of wrongful executions, a lack of hard evidence of the penalty's efficacy, and the increasing isolation of our position in the industrialized world? The explanations for this persistence ought to provide insight into the question of whether the death penalty is dying. Unfortunately, the conventional discourse on this topic fails to adequately address one essential aspect of the death penalty's tenacity. As I will argue, the persistence of the death penalty is incomprehensible without addressing the role of emotion.

The conventional discourse about capital punishment proceeds along certain wellestablished, highly circumscribed paths. In general, it tracks the usual philosophical debate about the purposes of punishment. The traditional assumption is that capital punishment must serve an instrumental goal: deterrence, retribution, or incapacitation. More recently, the notion that capital punishment might serve goals that are expressive in nature has gained currency. Questions about racial bias and systemic error are

\footnotetext{
* Distinguished Research Professor, DePaul College of Law. I wish to thank Austin Sarat for inviting me to write this article, and Joe Rollins and Scott Sundby for valuable comments on earlier drafts. I am also grateful to the faculty of New York Law School, and particularly Robert Blecker, and the faculty of Temple Law School, and particularly Peter Huang, Eleanor Myers, Muriel Morisey and Mark Rahdert, for their collegiality and their incisive comments on this paper. Finally, I am grateful to the anonymous reviewer for very helpful comments.
} 
counterpoised against these basic rationales, so that the question becomes whether these problems with the system outweigh or detract from the penalty's penalogical goals. This is the shape of the legal and philosophical debate about whether the death penalty is justified. It is also the outward face of the public debate about the death penalty, since that debate is often framed and summarized by social scientists and pollsters whose questions track the traditional discourse (Ellsworth and Gross 1994). ${ }^{1}$

The rather salient emotional content of the question of whether or when the state should kill is generally treated as a vexing and improper detour from the rigors of proper legal analysis or the scope of legitimate debate. This attitude toward emotion-a combination of denigration and denial-- shapes both the debate about whether capital punishment should be maintained as a legitimate punishment, and the debate about who should be executed. It creates a two-track discussion, in which one track is regarded as legally grounded, rigorous and acceptable, the other as illegitimate; not part of the accepted legal language or structure. The result is deleterious on two interrelated counts.

First, the "legally grounded" discussion, with its reference to time-honored but affectless concepts like "deterrence" and "incapacitation," fails to describe with any accuracy the way people actually arrive at decisions about the death penalty. The official "reasons" for the death penalty have only a tenuous connection to the real reasons why people support capital punishment. Researchers asking people why they support the death penalty repeatedly conclude that "most people's attitudes toward capital punishment are basically emotional. The 'reasons' are determined by the attitude, not the reverse." (Ellsworth and Gross 1994: 95).

\footnotetext{
${ }^{1}$ Moreover, the public opinion data is then cited in court opinions seeking to measure community attitudes. (Haney 2005 at 78, discussing Furman, in which public opinion was discussed in five of the Justices' nine separate opinions.)
} 
Second, the official discourse, as currently structured, perpetuates a misleading and problematic normative assumption: that the official reasons are devoid of emotion (except, perhaps, for a few carefully managed, "allowable" emotions). Capital punishment discourse too often operates on the assumption that rigorous, non-emotional reasons for or against the death penalty exist, but that the conversation keeps getting hijacked by unruly passion. I suggest that the reasons themselves, both the so-called instrumental reasons and the so-called expressive reasons, are imbued with emotional content. The demarcation between instrumental and expressive values is porous, and at bottom, both types of values are informed (or uninformed) by fear, outrage, compassion, selective empathy and other emotional attitudes. Or to put it another way, the decision whether or not to maintain and implement our system of capital punishment is inherently an expressive decision; one which is both inescapably moral and inescapably emotional. The official discourse masks, sanitizes or denigrates much of this emotional content. The result is not to banish emotion from the system, but to drive discussion of it underground, to privilege certain emotions, and to perpetuate a system that depends on moral and emotional distance and even disengagement.

The Court's approach in California v. Brown (1986), in which it upheld a jury instruction cautioning the jury that it "must not be swayed by mere sentiment, conjecture, sympathy, passion, prejudice, public opinion or public feeling," illustrates its misplaced faith in the existence of an emotionless realm and how it privileges certain emotions. (Brown 1986: 540) The Court was confident that jurors would understand this instruction as a prohibition on the exercise of "mere" or "untethered" sympathy, and would understand that they were still permitted to exercise mercy or compassion. Justice 
O'Connor, in her concurrence, explained that the instruction properly recognized the jury's decision as "a moral inquiry into the culpability of the defendant, and not an emotional response to the mitigating evidence.” (Brown (1986: 545) Even apart from the question of how juries are to distinguish sympathy, mere sympathy, mercy and compassion, the larger point is that the Court mistakes the nature of moral decisionmaking. Whether a juror votes to take or spare a life will depend in large part on empathy, distancing, anger, blame and other emotional variables; and these variables will constitute an essential component of his moral decision (Haney 1997; Sundby. 2005). When the juror tries in good faith to fit these moral and emotional reactions into a legal framework, he will often conclude that he has been instructed to put his empathy for the defendant "aside.” Because he has received no explicit instruction about anger, outrage, distancing, and even disgust, and has usually received both explicit ${ }^{2}$ and implicit messages that these states do not count as inappropriate or emotional, he is likely to conclude that they fit comfortably within the legal framework. ${ }^{3}$

Justice Blackmun’s dissent in Furman v. Georgia (1974), in which he "ignored the advice” Chief Justice Burger had given him "not to wear his heart on his sleeve," (Greenhouse 2005: 114) captures the determined struggle to "rise above" emotion in determining whether capital punishment is appropriate:

\footnotetext{
${ }^{2}$ For example, Justice Brennan's dissent in Saffle v. Parks, in which the jury had received an anti-sympathy instruction, quotes the prosecutor's language at length. At voir dire, in commenting on the instruction, the prosecutor told the jury, "And that's just as cold-blooded as you can put it...You can be as sympathetic as you want to...but you can’t do it and sit on this jury.” In his closing argument he said, among other similar comments, "You're not yourself putting Robyn Parks to death. You just have become a part of the criminal justice system that says when anyone does this, that he must suffer death. So all you are doing is you're just following the law....it's not on your conscience...God's law is the very same...So don't let it bother your conscience, you know.” 494 U.S. 1257, 1272-73 n13 (1990).

${ }^{3}$ See generally Craig Haney's book, Death by Design, for discussion of the many ways in which the capital punishment system is structured to create distance from the moral and emotional dimensions of the decision. As Scott Sundby observed, aggravating factors like 'especially heinous" or "vile" give the jurors arguing for a death sentence a "legal" factor that they can point to and say "see the law requires this-it is right here on the verdict form.” Letter from Scott Sundby to Susan Bandes, August 8, 2006.
} 
Cases such as these provide for me an excruciating agony of the spirit. I yield to no one in the depth of my distaste, antipathy, and, indeed, abhorrence for the death penalty, with all its aspects of physical distress and fear and of moral judgment exercised by finite minds...[A]lthough personally I may rejoice at the Court's result, I find it difficult to accept or to justify as a matter of history, of law, or of constitutional pronouncement. (Furman 1974: 414)

Ultimately, Justice Blackmun came to realize that the legal issues could not be neatly cabined in this way. In Callins v. Collins, he famously declined to continue to "tinker with the machinery of death" (Callins 1994:1145). His passionate description of an execution ${ }^{4}$ bespeaks a man who has long tried to grapple with capital punishment through the legal lens, but who can no longer distance himself from the fact that the death penalty involves the killing of a human being, and that the propriety of this state-sponsored killing is, at its crux, a moral and emotional question.

My contention is that the standard discussion about why we continue to executein the courts and the public forum-- fails, to its great detriment, to engage the crucial role of emotion. It treats emotion as an optional and indeed unwelcome commodity-the heart on the sleeve. It assumes a division between the "proper" or "acceptable" reasons to support or oppose the death penalty, and the emotional reaction that is viewed as the abdication of reasoning.

I will argue, to the contrary, that emotion is deeply involved in legal and moral judgment, in ways that are not optional or severable. Emotion affects how we interpret facts, categorize, discern patterns, identify norms and deviations from norms, and choose and prioritize among available options. It affects how we form our attitudes, values and

\footnotetext{
4 "The witnesses...will behold Callins, no longer a defendant, an appellant, or a petitioner, but a man, strapped to a gurney, and seconds away from extinction.” 510 U.S. 1141, 1143 (1994).
} 
beliefs, and how, once they are formed, we approach challenges to them. It affects what we find important, and what stirs us to action.

The standard discussion makes another important mistake about the nature of emotion: that it is private and internal. Emotion theory has become increasingly cognizant of the importance of understanding how emotions are affected by social interaction, and, in turn, how they affect societal notions of moral and ethical judgment (Haidt 2001). When emotion is approached as interactional, rather than merely private and internal, its study sheds light on the nature of legal institutions: both on how institutions channel, encourage and even help shape our emotions, and on how the institutions in turn reflect the social and ethical value judgments those emotions help to shape.

This article will begin by recounting the traditional rationales for the death penalty and raising some questions about their content and limitations. It will then discuss the essential role of emotion in every aspect of the death penalty system-its formation, its definition, its maintenance and its persistence. Finally, it will explore the implications of emotion's role for the question at hand: whether the death penalty is dying.

\section{The Traditional Rationales Revisited}

The standard arguments for capital punishment, familiar to any first year law student, are first, that it will deter others from committing similar crimes, second, that it is retributive in nature, meting out just deserts for the crime committed, and third, that it will permanently incapacitate the defendant so he cannot commit further crimes. ${ }^{5}$ These

\footnotetext{
${ }^{5}$ This is the theory of general deterrence. The theory of specific deterrence differs: it refers to the ability of punishment to deter the particular defendant from committing other crimes. There is some ambiguity in the literature as to the use of the terms "specific deterrence" and "incapacitation." Execution seems better described as incapacitating, in that it makes it impossible for the defendant to commit more crimes, rather
} 
penological theories are the subject of longstanding arguments which draw, implicitly and explicitly, from several types of authority. Deterrence arguments are viewed as utilitarian in nature, (Carter and Kreitzberg 2004), and thus based, at least implicitly, on empirical psychological assumptions about how people make decisions. Retributive theory, with its reference to what is morally right and deserved, is essentially nonempirical $^{6}$ (Radelet and Borg 2000). It is philosophically, and even theologically, based-for example, in its use of the lex talionis as a proper yardstick (Owens and Elshtain 2004: 4). However, retributive theory has undergone a shift, more recently drawing on psychologically based assumptions about the importance of punishment—and of participation in the sentencing process-- to victims and, in capital cases, to their loved ones. (Zimring 2003, Sarat 2001, Bandes 1996). Incapacitation arguments are harder to characterize, particularly in the capital context: they sound utilitarian (some murderers must be executed to prevent them from killing again) but the calculus requires both a means of determining which murderers will be incapacitated only by execution and a moral standard for determining which lives should be taken in the face of recidivist impulses. $^{7}$ As to all three theories, what is noteworthy is the scope of the traditional debate about whether we should execute people. It is oddly devoid of reference to emotion.

\footnotetext{
than deterring the defendant, which implies that it will convince him not to repeat the conduct. See Victor L. Streib, Death Penalty in a Nutshell 15 (2005).

${ }^{6}$ Although Paul Robinson and Robert Kurzban, for example, have conducted empirical studies attempting to measure moral intuitions about punishment. See Robinson and Kurzban (2006), Intuitions of Justice.

${ }^{7}$ Of course, all the aforementioned categorizations are highly oversimplified and indeed problematic. For example, retributive theory is sometimes characterized as utilitarian-it reaffirms the value of observing the law, thus creating a safer society. See e.g. Jeffrie Murphy, Legal Moralism and Retribution Revisited (Presidential Address to the American Philosophical Association, Pacific Division, March 24, 2006).
} 


\section{Retribution}

The omission is easiest to discern in the discourse on retributive theory. Retributivists "seek to punish an offender because she deserves to be punished in a manner commensurate to her legal wrongdoing and responsibility...Not more, not less.” (Markel 2004: 1439). Retributivists struggle to explain why meting out "just deserts" is the proper role of the state, and how to determine what amount of punishment is just (Duff and Garland 1995). Some retributivists define desert as simply legal guilt, and others have a broader view of guilt that incorporates moral blameworthiness. (Murphy 2006). ${ }^{8}$ Volumes have been written about these questions, and I do not intend to rehearse those debates here. What is interesting about standard retributivist arguments is that they present the need to punish the offender, as well as the ability to determine what punishment the offender "deserves," as bloodless and abstract philosophical questions. Retributivism is often portrayed as a way to avoid or civilize emotional reactions to crime, a means of determining the fair and just punishment from the community's point of view, rather than acquiescing to the punishment that the victim or the community might desire out of anger and vengeful feeling. (Markel 2004; Sigler 2000).

Indeed, retributivists tend to be especially eager to distance retribution from revenge. As Danielle Allen observes, "there is always...the worry that retribution is too close to revenge and is ugliness in tone, purpose and effect” (Allen 1999: 192). One

\footnotetext{
${ }^{8}$ In a recent article, Paul Robinson argued that the term encompasses three separate concepts which are used without sufficient distinction: vengeful desert (which focuses on the harm to the victim); deontological desert (which focuses on the blameworthiness of the wrongdoer) and empirical desert (which focuses on measuring the punishment commensurate with the community's intuitions of justice). Robinson, Paul H., "Competing Conceptions of Modern Desert: Vengeful, Deontological, and Empirical" (August 17, 2006). U of Penn Law School, Public Law Working Paper No. 06-32 Available at SSRN: http://ssrn.com/abstract=924917
} 
defender of retributivism hastens to assure us that it "isn’t just a fancy word for revenge ${ }^{9}$ ...and is not the idea that it is good to have and satisfy \{the emotion of vengefulness\}.” (Gerstein 1974:76). A similar aversion to the concept of revenge holds sway among jurors voting for death. Scott Sundby reports that a large proportion of jurors he interviewed identified the importance of their "desire to see justice done," though a very small proportion identified the importance of "feelings of revenge," and several were angered by the suggestion that revenge played a role in their decisions. (Sundby 2006: 127). He notes that similar results were found in a Gallup poll of the general population. (Sundby id). As Frank Zimring succinctly observed: "Vengeance is an anachronism with a bad press.” (Zimring 2003:58).

To what extent can retributivism, without reference to emotional affect, explain how societal or individual notions of fair and just punishment are shaped, particularly when the death penalty is at issue? What motivates a polity, or a community, to determine that the death penalty is the just desert for certain crimes? My contention here is not that the institution is fueled solely by the thirst for vengeance, or that jurors who vote for death are motivated solely by vengeful impulses. In fact, as I will argue, the emotional landscape is far more complex than that. Rather, I suggest that the traditional debate suffers for its insufficient attention to the emotional landscape in all its complexity. Without attention to emotion, retributive theory becomes circular, empty and

\footnotetext{
${ }^{9}$ Mary Sigler critiques Martha Nussbuam for collapsing retribution, retributivism and retributive anger. Sigler distinguishes retribution (a compensating reaction designed to restore the balance upset by an initial action) and retributivism (a theory of punishment based on the moral blameworthiness of wrongdoers, predicated on the assumption that the blameworthy are deserving of punishment) from retributive anger, which assumes anger and cruel excess. Mary Sigler, The Story of Justice: Retribution, Mercy, and the Role of Emotions in the Capital Sentencing Process, 19 Law and Philosophy 339, 348 n24 (2000).
} 
indeterminate-we punish because it is the right thing to do, and we mete out the punishment that is right.

There are two separate but overlapping questions: first, why the United Statesbut no other Western country, and thirty eight of the states-- but not the other twelve, consider the death penalty the "just desert" for certain categories of murder. Retributive theory has no good answer to this question. "Modern notions of desert are ordinal rather than cardinal.” (Robinson and Kurzban 2006). That is, they address where on the continuum punishment should fall, but not what types of punishment should bracket the continuum. ${ }^{10}$ Second, there is the question of why some jurors, in some cases, determine that a particular capital defendant deserves to die. Capital punishment in its 'idealized” form has always assumed the existence of a group of heinous offenders, the worst of the worst, for whom there should be consensus that death is a just desert. Perhaps such a consensus could exist in theory - the "McVeigh Factor," has become shorthand for the notion of crimes for which such a moral consensus might, hypothetically, come to exist (Sundby 2006:34; Sarat 2001:11). However, the idealized form bears little resemblance to the actual decision-making process engaged in by those faced with life or death decisions. In practice, the decision is - and always has been-- heavily influenced by a host of variables unrelated to the nature and circumstances of the crime.

As Jeffrie Murphy recently observed (or, more accurately, characterized Nietzche as observing) “our abstract theorizing—at least in moral theory-cannot fully be

\footnotetext{
${ }^{10}$ See Hugo A. Bedau, Retributivism and the Theory of Punishment, 75 J. Phil. 601, 613 (1978):

Although there may be little difficulty in making uniform judgments of ordinal culpability . . . or of ordinal harmfulness, there is no unique non-arbitrary way to combine these judgments into one judgment of ordinal seriousness .... Even if that problem is solved, and even if a plausible penalty scale can be constructed in terms of ordinal severity ... there is no unique non-arbitrary way to identify the severity of the appropriate punishment, given only the severity of the crime....
} 
divorced from its social setting and from our own personal human psychology, a psychology that may affect us in ways of which we are not fully conscious” (Murphy: 2006). Murphy's own work, in which he unsparingly examines his evolving retributivist impulses, is instructive. He at one point admitted to --and indeed defended--an attitude of "retributive hatred," but later became wary of the hardness and arrogance of that attitude. He remains a "reluctant retributivist" (Murphy 2006); the reluctance stemming from his awareness of the opacity of his own motives. (Murphy 1999). We should be similarly cautious when evaluating the fervent, frequent claim that retributivist philosophy in general, and retribution in sentencing in particular, are all about morality and justice, and not at all about emotion.

In contrast to standard retributivism, Robert Blecker has argued for what he terms emotive retributivism (Blecker 2006). He argues that the death penalty is the just and even obligatory punishment for certain crimes, not as a matter of undifferentiated vengeance, but as a means of giving voice to anger and rage toward the defendant, and to empathy for the victim's suffering. He argues that "moral desert can never be reduced strictly to reason, nor measured adequately by rational criteria: Forgiveness, love, anger, resentment are part of justice.” (Blecker 2003:198). Once these emotional wellsprings of the legal and moral calculus are thus acknowledged, a more clear-eyed debate about retribution's proper role in our capital punishment system can take place.

Both the retributive philosophy and the retributive impulse are better understood with reference to the emotional dynamics that help shape our intuitions of justice. These intuitions are affected by social and political context, for example by societal views of crime and what needs to be done to keep us safe. The attitudes of the populace might be 
better understood with reference to the constellation of emotional factors that influence moral reasoning (Hauser, Young and Cushman 2006; Haidt: 2001), and specifically, those that influence our individual and collective experience of crime, Perceptions of crime level and the danger posed by crime are formed in light of pre-existing templates about how the world works. ${ }^{11}$ The perceptions are also highly influenced by portrayals (for example media coverage or official pronouncements) that evoke strong emotions, including outrage, fear, the urge to blame, and--too often-- racial animus (Liebman 2002, Baldus and Woodworth 2004, Haney 2005). Indeed, as Markus Dubber argues, it is difficult to assess the justice of a regime of punishment without considering its ability to promote empathy and "counteract the natural tendency of antipathy toward the offender." Dubber 2006: 117). The attitudes of individual capital jurors in particular might be better understood by examining all these same factors, as well as the anger, fear, compassion, empathy or prejudice elicited by capital defendants.

We might also gain a more dynamic understanding of how attitudes about what constitutes just punishment are communicated. Retributive theory is expressive: it assumes that punishment-via both its threat and its infliction--performs a signaling function (Markel 2004), and thus is ostensibly concerned with the communication of norms and norm enforcement. Oddly, though, it pays little attention to how the signaling effect plays out in terms of identifying "just deserts." It fails to address how norms are communicated—both to the penal institutions and their actors, and to the populace.

It tends to assume a static model of top-down communication in which the signaling effect is achieved simply by the existence and enforcement of the law on the

\footnotetext{
${ }^{11}$ For an interesting treatment of the acute challenges pre-existing and preconscious assumptions (and the courts' unwillingness to address them) pose in a context other than capital punishment, see Andrew E. Taslitz, Willfully Blinded: On Date Rape and Self-Deception, 28 Harv. J. L. \& Gender 381-446 (2005).
} 
books (e.g. Markel 2004: 1445). To put it another way, it tends to assume that the message is communicated in a vacuum, rather than in concert with other forces which might amplify or distort its meaning. It is doubtful that the dynamics of signaling are ever that simple, but we know that in the capital context, they are much more complex. Attitudes toward the appropriateness of the death penalty are not developed or passed along in a static, top-down manner. Positions on the death penalty both draw from and are aimed toward a broader, more unruly, more interactive pool of knowledge and misinformation.

The standard model fails to consider, for example, the "audience effect" on the punishment calculus: the notion that the presence of an audience increases the measure of moralistic punishment (Kurzban et al 2006). This effect has been documented in the death penalty context, for example in studies by Stephen Bright and Patrick Keenan (1995) and James Liebman (2000) which found that the prospect of running for reelection causes judges to render more—and more flawed—death sentences. ${ }^{12}$

The "just deserts" calculus, when the death penalty is at issue, is influenced by media coverage (Bandes 2004), popular cultural representations of crime (Gross 1998), elections and other political pressures (Kurzban 2006; Bright and Keenan 1995; Liebman 2000), and folk knowledge (Steiner, Bowers and Sarat 2001), all of which tend to traffic in fear, anger and prejudice (Lipschultz \& Hilt 2002, Bandes 2004). The measure of just punishment, in the real world of capital litigation, is taken not in a vacuum, but in light of intense public pressure, raw emotion and political ambition.

\footnotetext{
${ }^{12}$ See also Justice O’Connor's concurring opinion in Republican Party of Minnesota v. White, 536 U.S. 765, 788 (2002), raising concerns about whether judges subject to reelection can decide controversial cases without violating the due process clause, and citing Bright and Keenan's findings. See also Freedman and Smith 2004: 248-49, discussing the due process issue.
} 
Emile Durkheim may be correct that our attempts to redefine the emotions underlying our penalogical impulses are merely cosmetic (Durkheim, 1984:46; Fisher and Chon: 4, 1989). At the very least, we mislead ourselves if we believe that the sanitized philosophical category of retribution does much work in explaining why we continue to execute.

\section{Deterrence}

The lack of attention to emotion's role in the debate about deterrence poses a different problem—-how to account for the fact that those who rely on this rationale do not change positions when confronted with evidence that deterrence fails to work as advertised. Deterrence theory posits that capital punishment will dissuade others from committing similar crimes in the future, and that it will do so more effectively than alternative sentences like life imprisonment. (Carter and Kreitzberg 2004). It is the most explicitly instrumental rationale for capital punishment, and the only one that makes what seems to be a testable empirical claim. Since capital punishment was held constitutional in the early 1970's, the deterrence rationale has been—until quite recently-- the primary justification cited for support of the death penalty (Radelet and Borg 2000). During the more than three decades of the modern death penalty era, as in earlier eras (Radelet and Borg 2000), little support has emerged for the empirical claim on which deterrence theory is grounded. Studies have occasionally purported to find a deterrent effect (see e.g. Ehrlich 1975, 1977 and Dezbakhsh et. al. 2002), though both the methodology of such studies and the uses made of their findings have been harshly criticized (see e.g. Blumstein and Cohen 1978, critiquing Erlich; Fagan 2004, Berk 2005 and Fagan et. al 2006, critiquing the recent spate of studies purporting to find that the death penalty 
deters). The "empirical standoff” Justice Stewart identified in 1976 still exists. As John Donohue and Justin Wolfers sum up the current state of empirical knowledge:

We are led to conclude that there exists profound uncertainty about the deterrent (or antideterrent) effect of the death penalty; the data tell us that capital punishment is not a major influence on homicide rates, but beyond this, they do not speak clearly. Further, we suspect that our conclusion that econometric studies are highly uncertain about the effects of the death penalty will persist for the foreseeable future.

Their bottom line: "Aggregating over all of our estimates, it is entirely unclear even whether the preponderance of evidence suggests that the death penalty causes more or less murder.” (Donohue and Wolfers 2005). ${ }^{13}$

In short, throughout the period during which deterrence was cited as the primary reason to execute, there was little if any reason to believe it worked. By the late 1990's, the public was becoming disenchanted with the notion of deterrence: it saw rising rates of execution yet did not believe crime was decreasing. Yet instead of withdrawing support for the death penalty, the populace simply shifted rationales. A decrease in support for the deterrence rationale began in the early 1990's, and has continued since (Gross 1998). By 2004, only one third of respondents to the Gallup Poll believed that the death penalty was a deterrent, compared to two thirds in 1985 (Sundby 2006: 29). Currently, "most Americans who favor the death penalty do so primarily for retributive reasons." (Gross 1998: 453). As Sam Gross put it, "changes in the level of belief in deterrence have had no obvious relationship to changes in support for the death penalty.” (Gross 1998: 454).

\footnotetext{
${ }^{13}$ But see Paul H. Rubin (2006). Reply to Donohue and Wolfers on the Death Penalty and Deterrence, The Economist's Voice 3, available at http://www.bepress.com/ev/vol13/iss5/art4 (last visited June 11, 2006).
} 
Put simply, in the capital context, the stated rationale is not very closely related to the depth or breadth of support. If we want to learn why people support capital punishment, and why, contrary to Justice Marshall's optimistic belief in the persuasive power of knowledge about the workings of the death penalty (Furman v. Georgia 1972), they do not change their position in the face of information refuting the rationale for their support, (Bohm et. al. 1990) we will have to look for less cognitively based explanations. ${ }^{14}$ Or more accurately, we need to understand how beliefs which purport to be cognitively based, are formed, and how, once formed, they are affected by additional information. As I will discuss shortly, such an understanding requires reckoning with the role of emotion.

\section{Incapacitation}

The incapacitation argument, when applied to the death penalty, holds that "we need to execute the most heinous killers in order to prevent them from killing again.” (Radelet and Borg 2000: 46). As one student guide put it, “Obviously, a foolproof means of physically preventing a specific killer from ever killing again is to take his life.” (Streib 2003: 15). The label “incapacitation” has an almost scientific, clinical ring to itit doesn't sound angry or uncivilized, the way the term "retribution" might. The emotional content of this justification operates below the radar. Yet the question posed is, inescapably, how we take the worth of a life. How do we decide a person is so irredeemable, and so threatening to our future safety, that he should be cast from the

\footnotetext{
${ }^{14}$ Nor does the efficacy of deterrence explain why people oppose the death penalty. As Ellsworth and Gross note, there are not nearly so many polls tracking the attitudes of death penalty opponents. The polls suggest that most opponents would continue to oppose the death penalty even if it were an effective deterrent. Their opposition tends to be based on the moral conviction that capital punishment is wrong, rather than on utilitarian considerations. (Ellsworth and Gross 1994: 19-52 )
} 
human community? ${ }^{15}$ This question draws on deeply held attitudes that are not cognitively based, including perceptions and fears about crime, empathy or lack of empathy, and beliefs about mercy, forgiveness, and adherence to rules. (Tyler and Weber 1982; Kahan and Braman 2005).

In addition, as with the deterrence rationale, there is the question of whether these attitudes are open to reappraisal in the face of contrary evidence. Here the results are mixed, but the influence of emotion is clear. "Fear is one of the most prominent factors influencing jury decisions to impose capital sentences. Specifically, juries are fearful that even if they impose a sentence of life without parole, the defendant will be released and perhaps cause more harm.” (Bandes 2004: 595). This fear reflects both “erroneous folk knowledge about length of sentence” (Bandes 2004: 595; Steiner, Bowers et.al. 1999) and "pervasive media images of the world as a dangerous and violent place in which the criminal justice system has done too much for criminals and not enough to keep lawabiding citizens safe.” (Bandes 2004: 595-96). On a hopeful note, once erroneous beliefs about length of sentence are acknowledged and addressed, they appear amenable to correction. (Garvey, Johnson et. al. 2000).

\footnotetext{
${ }^{15}$ There is a sense in which one might approach this as an empirical question, or rather two closely related empirical questions. The first is whether there is a class of murderers who are so dangerous, such committed recidivists, that if they were freed they would kill again. The second is whether execution is the only way, or the best way, to prevent such people from killing again. Both questions have been approached empirically. On the issue of recidivism, for example, a study was done to determine how many of those whose death sentences were commuted after Furman went on to kill again (Marquart and Sorensen 1989; reprinted in Bedau 1997), and it determined that only about one percent went on to kill again, about the same as the number later found to be innocent. (Radelet and Borg 2000: 46). On the issue of whether execution is necessary to incapacitate for life, there is empirical evidence that, under modern penal conditions and in light of the availability of life imprisonment without parole, prison is equally effective. (Radelet and Borg 2000: 46).
} 


\section{The Expressive Rationales Compared}

The traditional theories of punishment have always generated unease and a sense that something essential about why we punish remains unexplained (Allen 1999). When these theories are pressed into service to explain why we execute, their limitations are revealed to be particularly acute. The defects of the classical theories have motivated "expressive" theories ${ }^{16}$ of punishment, under which punishment is inherently justified as a means of expressing symbolic defeats on wrong-doers, educating both criminals and law-abiding citizens, denouncing the criminal act, and communicating the content of society's moral rules. (Steele 2001:36)

David Garland recently observed that

capital punishment is largely an expressive measure today, held in place chiefly by emotionally charged political considerations rather than by moral instrumental concerns such as deterrent crime control. (Garland 2005:349).

Assuming capital punishment is expressive, what does it express? Does it express a societal commitment to living by moral rules, (Durkheim 1984:58) the strongest possible condemnation of those who break the rules, (Feinberg: 1970) recognition of the moral worth of the victim, (Murphy and Hampton 1988) a desire to bring the victim's loved ones back into the community by giving voice to their anger and grief (Allen: 1999), the public enactment of revenge on the victim's behalf, (Sarat 2001) reassurance that the world is an orderly rather than a chaotic, unsafe place, (Haney: 2006) a collective cry of outrage and pain, (Durkheim 1984) the desire to purge evil from the community?

\footnotetext{
${ }^{16}$ There is a rich literature about the expressive functions law serves, not only in the punishment context, but more generally. See e.g. Cass R. Sunstein, On the Expressive Function of Law, 144 U. Pa. L. Rev. 2021 (1996).
} 
(Lifton and Mitchell 2002: 251) ${ }^{17}$ The correct answer must be: all of the above, at least in some measure and at one time or another, and moreover, these expressive purposes are inextricably bound up with the instrumental concerns as well. The demarcation between traditional and expressive punishment leads us astray.

At the outset, I should note the confusion of the normative and descriptive that can muddy this debate. The traditional justifications for capital punishment are just thatarguments for the appropriateness of capital punishment. Expressive theories are sometimes billed as justifications for punishment, and sometimes as better, more accurate accounts of why we punish. Or at times, the very label "expressive" is used as a critique, counterpoising emotional and political concerns against instrumental, pragmatic concerns. As David Garland acutely observes, this way of dividing up penological purposes "implies a definite ranking" between an "instrumental part...which gets things done" and a "symbolic part...that is merely decorative or discursive and appears to have no substantive function” (Garland 1990: 10).

The question of why the death penalty persists cannot be answered without reference to the expressive dimension of capital punishment. More accurately, the explanations are expressive all the way down. As I discussed above, retribution is explicitly expressive; all its benefits flow from the communication of the existence and implementation of punishment. Deterrence, though not often classified as such, is explicitly expressive as well. It is premised on the belief that would-be murderers will desist based on the advertised consequences to others before them. Punishment—and certainly capital punishment—is always a "deeply symbolic event” (Garland 1990: 10)

${ }^{17}$ Another fascinating point for debate is whether these expressions are political and fluid, as David Garland suggests, (Garland 2005) or cultural and more deeply rooted, as Frank Zimring suggests (Zimring 2003). 
and we---as individuals and members of the polity-construct and understand that symbolism in a way that is not purely cognitive. Attitudes about whether the social order “requires” capital punishment, or about whether certain people “deserve” to die, or about which sorts of victims might be "owed" this punishment, are imbued with symbolic value. Moreover, they are premised on assumptions about how the world works, and how it ought to work. There are no "moral instrumental” concerns or purely legal justifications that float free of emotional and political influence, or of communicative content. And just as our American death penalty is an expression of culture, politics, religion and other values, these values are themselves intricately tied to, and in many respects a product of, our emotional commitments.

\section{The Essential Role of Emotion}

The longstanding debate about the death penalty is intense, even polarized, despite (or perhaps, as I will discuss below, because of) the fact that the death penalty has little direct impact on most people (Ellsworth and Ross 1983). To understand why our society continues to support the death penalty, and whether we are likely to abandon that support any time soon, we must first consider how people arrive at moral judgments and under what conditions they will reconsider these judgments. The standard assumption, and certainly the bedrock legal assumption, is that people encountering a moral dilemma engage in moral reasoning, that this reasoning leads to a judgment, and that "emotion may emerge from the judgment, but is not causally related to it.” (Hauser, Young and Cushman 2006:6). This assumption is noteworthy both for its chain of causality and for its treatment of moral reasoning as individual and internal. Although there is no unanimity about how moral reasoning works, it is fair to say that this standard model is 
under serious attack, particularly in light of recent findings in cognitive and social psychology calling its descriptive accuracy into question.

The phenomenon that perplexes those who study capital punishment, the stickiness of support for the death penalty even when the grounds for that support are shown to be spurious, is a nice illustration of what psychologist Jonathan Haidt calls “moral dumbfounding." He noted that groups interviewed about their attitudes toward hot button issues:

were often "morally dumbfounded.”; that is, they would stutter, laugh, and express surprise at their inability to find supporting reasons, yet they would not change their initial judgments...(Haidt 2001:817)

This effect has been observed in numerous studies, many using neuro-imaging techniques like fMRI and PET scans, whose results challenge the notion that moral reasoning is the cause, rather than the consequence, of moral judgment. These findings have generated alternative models of moral reasoning. For example Haidt's social institutionalist model posits that emotion triggers judgment, and that reasoning occurs after judgment, offering a "post-hoc rationalization of an intuitively generated response” (Haidt 2001). Another model, advanced by Antonio Damasio and others, posits that every moral judgment is the product of both emotion and reasoning (Damasio 1994), or, alternatively, that emotion is triggered in moral dilemmas of a personal nature, whereas reason prevails in situations of a more impersonal nature (Greene et al 2001; Hauser 2006).

One problem with discussing and interpreting such theories, particularly across disciplines, is the lack of any agreed upon definition for the term emotion. To say, for example, that moral judgments are the product of both emotion and reason is to 
counterpoise the two terms and risk replicating an emotion/reason divide that should not be replicated (Bandes 1999). This is not the proper place for an abstract discussion of this age-old problem, and as I argued earlier, a more complex understanding of the role of emotion renders the divide far less pronounced. For current purposes, an examination of the ways in which attitudes toward the death penalty are shaped will help illustrate both the malleability of the terms and the application of the moral reasoning debate to the question at hand.

If we categorize "deterrence" and "retribution" and "incapacitation" as reasons for supporting the death penalty, and "fear" "forgiveness" and "outrage" as emotions that hijack the reasoning process, we will likely conclude, with the social scientists who have studied the matter, that “most people’s attitudes toward capital punishment are basically emotional. The 'reasons' are determined by the attitude, not the reverse.” (Ellsworth and Gross 1994: 95). But if this conclusion implies that there is a realm of "pure reason" that could operate if only we could cordon off the emotions that continually interfere, then it should be approached with caution. Instead, social and emotional concerns are an inextricable part of the reasoning process itself.

Emotion affects our evaluation of capital punishment at the most basic level. Our pre-existing attitudes ${ }^{18}$ about how the world works affect our beliefs about particular issues. Indeed, particularly when the attitudes are deeply held, they protect our beliefs from contradictory or threatening information. They affect the way we process and evaluate information. They affect whether we even consider new information, what

18 Attitude is sometimes defined as "the psychological predisposition or tendency to respond to an entity with a positive or negative evaluation." (Herek 2004: 17). Dan Kahan refers to what he calls "cultural commitments," (Kahan 2006: 148) and others refer to "implicit theories" (Dweck et al. 1995: 276.) These terms generally refer to the same concept: templates about how the world works and how people behave, not necessarily consciously held. 
category we assign it to, how much importance we give it, and how much we care about it. Research on motivated reasoning has shown that when people become aroused-- i.e. motivated to arrive at a particular conclusion or to support a particular belief-- they begin screening out contrary information at a very early stage. They search memory for beliefs, heuristics and rules that support their desired conclusion, but they do not realize that they are engaging in a biased process. They attempt to construct a persuasive rationale for their desired conclusion, so that it looks, even to them, as if they are engaging in an open minded process of reasoning (Kunda 1990: 495). Hence Haidt’s “moral dumfoundedness effect”: people are resistant to information that contradicts their pre-existing attitudes and often turn away such information at an early stage, but they are not conscious that they are doing this. (Kunda 1990: 490, Bandes 2006, Burke 2006).

For example, how should the question of whether the death penalty is an effective deterrent be approached? It requires some notion of how people will behave when faced with the threat of draconian (and, in most cases uncertain) consequences. It also requires a sense of whether the draconian consequence of taking a life is called for. In order to answer these questions, people draw—intuitively or consciously—on their attitudes about how the world works. For example, some people see others as possessing fixed, unchanging moral traits; some see others' moral traits as malleable and dynamic (Dweck 1995: 276). These assumptions about character and behavior will likely influence one’s assessment of whether people can change their behavior in the face of threatened consequences (Blumenthal 2006). Then there is the question of what sorts of people one might imagine when thinking about whether would-be murderers learn by example. What sorts of people are in the category of would-be murderers? (Osofsky et. al. 2005: 375) 
Are they people for whom we might feel empathy or forgiveness, or evil, irredeemable people, or people from a different demographic world—one which may evoke hostility, fear or prejudice? Moreover, the question of whether the "ultimate" deterrent is necessary implicates emotion laden attitudes about criminality, how it affects our safety, and how our safety might be best safeguarded. How fearful are we about the world around us? Does it feel chaotic and scary? Are we outraged by the government's failure to protect us, and would we feel reassured if something visible and punitive were being done? What are our attitudes toward law enforcement—-trusting, deferential, or concerned about fallibility and corruption? Each of us shows up for the general debate with a world view, and this world view is emotional as well as cognitive.

Ellsworth and Ross found that attitudes toward the death penalty were emotionally based, and preceded, rather than stemmed from, reasoned beliefs, so that, for example, while "a belief in the relative deterrent efficacy of capital punishment is almost perfectly correlated with support for it...this belief cannot be considered a major reason for this support” (Ellsworth and Ross 1983: 162). Tom Tyler and Renee Weber, in a study seeking to measure whether support for the death penalty was instrumental or symbolic, concluded that "political and social attitudes are the major source of beliefs concerning the retributive value, deterrence value, and humanity of the death penalty.” (Tyler and Weber 1982:41). They argued that the attitudes affecting death penalty support are basic, highly affective, pre-cognitive attitudes toward the world, such as liberalism, authoritarianism and dogmatism. These attitudes precede the formation of beliefs about particular issues, for example beliefs about the value of retribution or deterrence, and the beliefs that develop will support the initially formed attitudes (id). 
Tyler and Weber conclude that support for the death penalty is symbolic rather than instrumental. I draw a different lesson from these studies: that the distinction between the symbolic and the instrumental is not descriptively useful in this context. The way we view the world will affect both our notions of the efficacy of instrumental punishments and our sense of what punishment ought to express. In other words, those who support the death penalty will both think it works and agree with its symbolic message. For example, for those who see the world in terms of individual responsibility and deference to authority, the death penalty may seem to be a practical deterrent, and also a proper symbol; an expression of the strongest possible condemnation of deviant behavior. Those whose world view encompasses concerns with racial inequality or societal causes of crime are likely question the death penalty's ability to deter, and to disapprove of its symbolic repudiation of the possibility of forgiveness and redemption. (Kahan 2006: 157). The death penalty serves, always, as both a concrete policy and an abstract symbol—either of toughness, control and certainty, or of inequality, vengeance and irreversible error. It projects a set of values, and to the extent those values are emotionally resonant, and consonant with the values of the population, it is viewed as legitimate (Baldus and Woodworth 2004: 1427; Zimring 2003: 127).

\section{The Feedback Loop}

The emotional resonance that permits the death penalty to maintain its aura of legitimacy is a dynamic, interactional emotional state. The view of emotion as private and internal is a barrier to understanding a process that in fact takes shape in a social and cultural context ${ }^{19}$ (Hochschild 1983). Emotion exists in a complex feedback loop with

\footnotetext{
${ }^{19}$ Recently, albeit more than two decades after the publication of her landmark work The Managed Heart, the field of sociology has taken up Arlie Hochschild's challenge to consider emotion in dynamic,
} 
institutions like the justice system. It has a role in shaping our institutions, and the institutions in turn have a role in shaping emotions - their expression, their display, and even, arguably, their inchoate nature. As Martha Nussbaum argues, we construct institutions that embody what we value (Nussbaum 2001: 405). The continued existence of the death penalty is a societal declaration that death is the appropriate punishment for the most terrible crimes. This declaration rests on a complex and evolving legal/moral/emotional judgment about what we require in order to restore the sense of order and justice that are disturbed by a heinous crime. Thus, over the years, it has been possible to chart shifts, not only in public attitudes toward capital punishment, but in the emotional content and the emotional rhetoric of those attitudes. ${ }^{20}$ For example, where once it was considered harsh and unenlightened to rely on retributive theory in support of the death penalty, in recent years it has become acceptable and common. As David Garland put it,

the background affect of policy is now more frequently a collective anger and a righteous demand for retribution than a commitment to a just, socially engineered solution. The emotional temperature of policymaking has shifted from cool to hot. (Garland 2001:10-11).

At the same time, the language of emotion and therapy has become welcome in the courtroom, as acknowledging the worth of victims and providing a forum for “closure” and healing to their survivors have become central goals of capital punishment

institutional contexts, as exciting new work addresses the sociology of emotions. See e.g. Turner and Stets 2005.

${ }^{20}$ See, for example, V.A. C. Gatrell's The Hanging Tree: Execution and the English People, 1770-1868 (Oxford: Oxford University Press, 1994), and Randall McGowen, A Powerful Sympathy: Terror, the Prison, and Humanitarian Reform in Early Nineteenth-Century Britain (1986) The Journal of British Studies 25, 312-334, discussing the shifts in the emotional meaning of public execution-and in the evolution in "public emotion" generally, in eighteenth and nineteenth century Britain. 
(Zimring 2003: 57-63, Bandes 1996, Bandes 2000). These institutional goals play a role in shaping emotions, by creating a set of emotional expectations that must be responded to. For example, the existence of the penalty has created an expectation that only capital punishment will truly honor the dignity and worth of the victim. This expectation has serious consequences. Despite the recommendations of numerous blue ribbon commissions to narrow the list of death eligible crimes, legislators come under pressure to expand the list in order to demonstrate the value of the lives of the victims in each category. As Scott Turow observed: "the fundamental equality of each survivor's loss creates an inevitable emotional momentum to expand the categories for death penalty eligibility.” (Turow 2003) Prosecutors routinely assure jurors that a death sentence is owed to the victim and the victims' survivors. Thus jurors are signaled that death is the default sentence, and that failure to impose it betrays the dead and the bereaved. Family members and other survivors of murder victims are encouraged to feel that they are entitled to a death sentence, and even that the failure to impose a death sentence is an additional infliction of pain they must bear. ${ }^{21}$

The trial court has been drafted into a therapeutic role, without much thought for whether it can or should serve that purpose (Henderson: 1985). Based on the questionable concept of closure, survivors ${ }^{22}$ are assured that the execution will at last allow them to move on with their lives (Lithwick 2006). Survivors have also been assured that only a

\footnotetext{
${ }^{21}$ For more extensive discussion of the role of victims and the concept of closure in capital cases, see Bandes 1996 and Bandes 2000.

${ }^{22}$ The question of who should be treated as a survivor for this purpose is sometimes complex, and never more so than in prosecutions for mass murder. See, for example, Wayne Logan's discussion of the use of victim impact testimony in the sentencing hearing of Zacharias Moussaoui for his role in the September $11^{\text {th }}$ attacks. As Logan recounts, the court permitted former mayor Rudolph Guliani and others to testify to the impact of the murders on institutional victims like the New York Police Department and the City of New York, a decision which greatly upset some of those who lost close relatives in the attack (Logan 2006.)
} 
death sentence can heal their wounds, and efforts to truncate the appellate process have been premised on the survivors' need to attain closure (Bandes 2000, Zimring 2003: 5763).

Thus the feedback loop perpetuates itself. We have the system we think we need, and it drives us to need the system we have. But the story is complicated. As Frank Zimring points out, the death penalty died in Western Europe despite broad popular support. It was abolished by those in leadership positions, and yet its abolition did not create an outcry from the populace (Zimring 2003: 22-24; Lifton and Mitchell 2002: 247). It seems unlikely, at least in today's political climate, that U.S. leaders could (or would) play the same role, ${ }^{23}$ and the reason is not so much the breadth of American support for the death penalty, but the intensity of the support. The differences between the European and American approaches to capital punishment raise complex historical, political and social questions which scholars like James Q. Whitman (Whitman 2003), Garland, Lifton, Zimring and others have considered in depth, and which cannot be considered in detail here. My contention is that emotion theory, and particularly the role of salience, help illuminate the sources of that intensity, as well as a possible way to move the conversation forward.

\section{Salience}

Salience is a term in technical use in psychology, neuroscience, semiotics and other disciplines. Although there are variations in meaning across and even within these

\footnotetext{
${ }^{23}$ Taking a strong position against the death penalty is generally a surefire recipe for political suicide. See e.g. Alan Berlow, The Wrong Man at 80, The Atlantic Monthly, November 1999 ("it is highly implausible that a candidate who refused to take a strong position in favor of the death penalty in a judicial election race\} could be elected"). See also Bandes 2004: 595-96; Kropf 2006 (quoting William W. Wilkins, chief judge of the U.S. Court of Appeals, Fourth Circuit, as saying "No one \{in South Carolina\} can be elected to statewide office who is opposed to the death penalty.”)
} 
disciplines, the term generally refers to the accessibility, intensity, or attention-getting properties of an event or other entity, and so I will use it here (see e.g. Yen and Finkel 2002). Salience is key to understanding the role emotion plays in decision-making. Emotion "acts as a great emphasizer and highlighter in the brain, an indicator of importance and urgency” (Goodenough and Prehn 2004: 1717). It helps determine what we will keep in the forefront of consciousness and what will drive us to act; e.g. what is salient. Salience is key to understanding—and perhaps changing-- both the societal and individual dynamics that have led to the persistence of capital punishment in the United States.

A unique aspect of the death penalty debate is the strange confluence between the broad intense public debate on the topic and the lack of personal exposure to the capital system. As Ellsworth and Gross observed:

Capital punishment is an issue that is far removed from most people's direct experience. Few Americans have ever sat in the jury box or the dock in a capital case, or spent much time with condemned prisoners, or known a victim well. And yet most people have opinions about capital punishment that are strong, definite, and difficult to change (Ellsworth and Gross 1994: 161).

The intensity of public opinion on the topic is significant for a number of reasons. As we saw above, people often engage in motivated reasoning that leads them to ward off any information threatening to their beliefs. They go to great lengths to reaffirm what they "know," turning away conflicting specialized knowledge or subjecting it to different or higher standards of accuracy (Bohm, Clark and Aveni 1990:181). As one researcher put it, subjects would "twirl the emotional kaleidoscope until it gave them a picture that was comfortable.” (Vedantam: 2006). People do not always reason this way, and in some 
cases they can be primed to strive for accuracy and therefore to remain open to new information. Motivated reasoning might be triggered by the need to feel good about, or reduce cognitive dissonance about, one's own actions and choices. Significantly, it might also arise from a desire to cling to strongly felt pre-existing beliefs about the world, even in situations that do not directly impinge upon one's life. It is not surprising that this effect has been observed in the capital punishment context (Lord, Ross and Lepper 1979; Baldus and Woodworth 2004: 1431), a context in which Americans do not merely hold opinions, they “care a great deal” (Ellsworth and Gross 1994: 161).

The intensity of belief contributes not only to the solidifying (or ossifying) of individual opinion, but to the polarization of group opinion. As Kahan and Braman observe, "the tendency of individuals to trust only those who share their orientation makes the belief-generative power of culture feed on itself.” (Kahan and Braman 2006: 154). Particularly with the sorts of symbolic, hot button issues that are "strongly connected to an individual's cultural identity," (Kahan and Braman 2006:164) the effect of additional information is often, perversely, to reinforce the chasm between opposing groups.

The deeply held feelings underlying the debate may be essential to understanding how the United States got left behind as most of the industrialized world moved toward abolition. As Zimring argues, although the top-down policy change in Western European countries did not much affect the breadth of support for the death penalty in those countries, it also did not provoke the backlash that would likely occur in the U.S., in which the popular investment in the policy is much stronger (Zimring 2003: 127; see also Whitman 2003: 15). 
The mix of intense emotional investment in the issue, polarization, and lack of exposure to the facts on the ground is lethal. The conversation might begin couched in terms of deterrence or retribution, it might move to broader attitudinal claims about federalism, vigilantism, and crime control, but it does not take long to get to the ultimate polarized place, in which one side is arguing for purging the society of evil and the other side is calling the first side evil for advocating murder. At that level of high stakes abstraction, the prospects for nuanced conversation are bleak.

At this pass, salience is again relevant; indeed, it may offer the way out of the stalled conversation. At one level, the highly abstract conversation is peculiarly sensitive to high profile events and trends. It has long been shaped by perceptions of violent crime, such as those driven by constant, sensationalized images of random, racialized violence (Haney 2005; Bandes 2004). It has been fueled by certain high visibility crimes, particularly the Oklahoma City bombings, which provided Timothy McVeigh, the poster boy for capital punishment. But it has also worked the other way, responding to the occasional high profile execution of a sympathetic person, for example Karla Faye Tucker, and to high profile exonerations like that of Rolando Cruz. These cases have elicited an accessible set of countervailing moral imperatives. The DNA exoneration cases in particular have been effective in part because they provide vivid, easy to grasp illustrations of the unfairness and immorality of executing someone who has been scientifically shown to be innocent. ${ }^{24}$ Lifton and Mitchell argue that it was just this sort of

\footnotetext{
${ }^{24}$ However, the Supreme Court has been highly reluctant to recognize claims of actual innocence, or to ease the procedural barriers to their recognition. See e.g. Schlup v. Delo, 513 U.S. 298 (1995) (creating high bar for habeas petitioners seeking to avoid procedural default through claim of actual innocence) and Herrara v. Collins, 506 U.S. 390 (1993) (creating extraordinarily high bar for habeas petitioners seeking to raise freestanding claims of actual innocence). Most recently, in Bell v. House, 539 U.S. 937 (2003), the Court appeared to suggest that the lower courts had been a bit too demanding in their application of the Schlup standard. Yet the Court declined to find the Herrara standard met in that case, despite recognizing
} 
moral outrage over individual miscarriages of justice that helped pave the way for abolition in some Western European countries (Lifton and Mitchell 2002: 248).

But the exoneration cases illustrate a difference, more nuanced point about salience. People are often able to pierce or move beyond abstractions when confronted with actual human lives in all their complex, messy concreteness. This is one well-known finding of the "trolley" experiments ${ }^{25}$ examining the cognitive mechanisms that affect moral decision-making. We approach a moral dilemma quite differently if we experience it as directly affecting us or those we care about (Greene, et. al.2001). This difference has enormous significance for the death penalty on both the individual and societal levels.

One of the most important characteristics of the capital trial is the insistent message that the issue of whether the defendant should live or die is not an emotional issue. The very appearance of dispassionate process is an important part of the system's emotional landscape; a powerful implicit message to the jury as well as the other legal actors (Haney1997). In numerous ways the message is conveyed: You are not making a profoundly disturbing ethical choice about the taking of a life. You are not directly responsible for the taking of a life; you are just one link in a complex chain. That is, the conditions needed for moral disengagement are created, including the sanitizing of the decision to kill, and the diffusion of responsibility for the decision (Haney 1997;

that it was is more likely than not that no reasonable juror would have lacked a reasonable doubt of the suspect's guilt had they been privy to the now-available DNA evidence. See also Susan Bandes, Simple Murder: A Comment on the Legality of Executing the Innocent, 44 Buffalo Law Review 537 (1996). See also Shaw, Wrong on Wrongful Executions, contradicting Justice Scalia's recent claim in his concurrence in Kansas $v$. Marsh that there has not be "a single case-not one-in which it is clear that a person was executed for a crime he did not commit.” Kansas v. Marsh, 126 S. Ct. 2516, 2533 (2006).

${ }^{25}$ These are artificial dilemmas, whose parameters can be manipulated, which are designed to test the dynamics of moral judgment. One well known study concluded that those dilemmas experienced as personal affected different areas of the brain and led to different moral reasoning processes from those experienced as impersonal. Greene, Joshua D., Sommerville, R. Brian, Nystrom, Leigh E., Darley, John M. and Cohen, Jonathan D., An fMRI Investigation of Emotional Engagement in Moral Judgment (2001). Science 293, 2105- But see Hauser (2006) (questioning whether the impersonal/personal dichotomy explains results of studies.) 
Osofsky, et al 2005). But jurors confronted with wrenching cases often find this dispassion and detachment impossible to attain. Scott Sundby quotes one such juror as saying "You develop all these theories about the death penalty and the criminal justice system, but being in it is different. You come to grips with what you really think and feel” (Sundby 2005: 171). Alex Kotlowitz described how a jury of men and women who strongly favored the death penalty as an abstract matter came to spare the life of Jeremy Gross, a capital defendant whom they had convicted of a brutal murder. He recounts how the jury, learning about Gross’s own brutal childhood, gradually came to understand him and even to empathize with various aspects of his life. At first, jurors could not look him in the eye, and they adjudged him to be cold and indifferent. As they got to know more about him, they reread his demeanor, viewing what they initially thought was indifference to be shame. Their empathetic connection was crucial to their eventual decision to spare him (Kotlowitz 2002).

Making the stakes concrete will not always work against the death penalty. Prosecutors use victim impact statements, for example, to make the victim's suffering salient and thereby encourage a death sentence. ${ }^{26}$ Nevertheless, defense attorneys understand how crucial it is that juries hear the more elusive counter-narrative of the defendant's humanity; and that they do not distance themselves from the defendant's pain, the possibility of his redemption, and their own responsibility in determining his fate (Bandes 1996).

\footnotetext{
${ }^{26}$ The Moussaoui verdict was interesting in this regard. Moussaoui is the only person yet to be tried in a U.S. courtroom for the September $11^{\text {th }}$ attacks. More than three dozen family members of those killed in the attacks gave victim impact testimony. The jury (which was reportedly quite divided on the issue) did not sentence Moussaoui to death, partly because of lingering doubt about his role in the plot. As the New York Times put it, "The Moussaoui jury acted as capital juries typically do. It accepted the government's argument in the abstract, but, when push came to shove, it stopped short of sending the defendant to his death.” Adam Liptak, Moussaoui Verdict Highlights Where Juries Fear to Tread, The New York Times as A21 (May 5, 2006).
} 
As Scott Sundby recently observed, the death penalty might die because of a sea change, or because of a "death by a thousand cuts" (Sundby 2006). Either scenario depends on piercing the veil of abstraction. There is ample evidence that the death penalty is at its most desirable when at its most abstract and symbolic. When people are confronted with concrete information about actual defendants, ${ }^{27}$ the mechanics of lethal injection or other execution methods, or alternatives like life without parole, support for the death penalty lessens considerably (Haney 2005: 90). As Lifton and Mitchell put it:

people embrace the principle as a psychological source of security-which turns out to be fragile because it is readily threatened by whatever reminds them that execution is a form of killing (Lifton and Mitchell 2002: 252).

\section{Concluding Thoughts: Claiming the Emotional Terrain}

The debate about the death penalty is too often conducted in parallel rhetorical worlds. The traditional discussion about the purposes of punishment is based on assumptions about what count as legally and philosophically rigorous grounds for punishment. It divides up the world in a way that relegates certain concerns to the devalued realm of the decorative, the symbolic, the emotional, and views this realm as soft and illegitimate. When legal scholars, jurists and social scientists participate in the discussion on such terms, they become demoralized by the disconnect between "proper" reasons and the actual dynamics of the death penalty. I suggest that this disconnect is in part based on a misunderstanding about the role of emotion in the reasoning process. As I have often argued, the idea that emotion pervades the law poses a threat to law's most

\footnotetext{
${ }^{27}$ Or, for that matter, actual victims and survivors, some of whom do not want the death penalty. Bandes (1996) and Bandes (2000). The voices of victims are sometimes suppressed in capital sentencing hearings when they do not advance the prosecution agenda. For example, in the sentencing hearing of Timothy McVeigh, the prosecution barred testimony by the mother of a child killed in the Oklahoma City bombing because she opposed the death penalty (Bandes 1999: 341).
} 
cherished self conception. Unfortunately, to ward off that idea is simply to perpetuate and insulate the current emotional landscape; not to banish emotion from the legal process. In the conventional view, opposition to capital punishment is often denigrated as emotional and moral, and therefore lacking in the rationality and tough-mindedness the law requires. Yet those who support the death penalty tend to be driven by passion as well, a passion that is not fueled by legal, doctrinal concerns. The current system of capital punishment is rife with fear, anger, selective empathy, blame, and the desire for revenge; all clothed or camouflaged in the language of rational legality. To avoid the discussion is simply to cede the ground.

We can allow ourselves to be borne along on waxing and waning emotional tides - fears, panics, and sympathies—or we can address the emotional issues directly. Arguably the direct approach proved quite successful for the pro-capital punishment camp; the emotional meaning of capital punishment evolved noticeably in the face of the victims' rights movement. When the deterrence rationale began to lose force, the new language of therapeutic healing and closure provided a way to maintain support without facing the ugly question of how much retribution resembles revenge.

The death penalty thrives under a set of rules, explicit and implicit, about what sorts of emotions can be displayed and even experienced in the legal arena. These rules encourage moral disengagement and discourage empathy. They keep the concrete reality of the death penalty at a safe remove. Most of those who support the death penalty do so in the abstract. Their support often wanes when they become viscerally aware of the fact that capital punishment involves the killing of human beings. Certain realities need to be made salient: the humanity and individuality of each capital defendant, the horror of the 
execution itself, and the fact that each of us is implicated in and responsible for each execution and for the system that facilitates state-sponsored killing. These realities are at the moral and emotional center of the American system of capital punishment, and they should be at the center of the debate about its fate. They should incite passion and commitment. When that happens on a broad scale, the death penalty will die its welldeserved death. 


\section{Bibliography}

Allen, Danielle S. (1999). Democratic Dis-ease: Of Anger and the Troubling Nature of

Punishment. In Susan Bandes (Ed.), the Passions of Law (pp. 191-216). New York: New York University Press.

Baldus, David C., Woodworth, George and Pulaski, Charles A. Jr. (1989). Equal Justice and the Death Penalty: A Legal and Empirical Analysis. Boston, MA: Northeastern University Press.

Baldus, David C. and Woodworth, George (2004). Race Discrimination and the Legitimacy of Capital Punishment: Reflections on the Interaction of Fact and Perception. DePaul Law Review 53, 1411-1496.

Bandes, Susan (1996). Empathy, Narrative, and Victim Impact Statements. University of Chicago Law Review 63, 361-412.

Bandes, Susan (1996). Simple Murder: A Comment on the Legality of Executing the Innocent. Buffalo Law Review 44, 501-525.

Bandes, Susan (1999). Victim Standing. Utah Law Review 1999, 331-347.

Bandes, Susan (2000). When Victims Seek Closure: Forgiveness, Vengeance and the Role of Government. Fordham Urban Law Journal 27, 1599-1606.

Bandes, Susan (2000). The Passions of Law. New York: NYU Press.

Bandes, Susan (2004). Fear Factor: The Role of Media in Covering and Shaping the Death Penalty. Ohio State Journal of Criminal Law 1, 585-597. 
Bandes, Susan (2006). Loyalty to One’s Convictions: The Prosecutor and Tunnel Vision. Howard Law Journal 49, 475-494.

Berk, Richard (2005). New Claims About Executions and General Deterrence: Déjà vu All Over Again? 2 J. Emp. Legal Stud. 303-330.

Blecker, Robert (2003). Roots: Resolving the Death Penalty: Wisdom from the Ancients 169-231, in Acker, Bohm and Lanier, America’s Experiment with Capital Punishment:

Reflections on the Past, Present, and Future of the Ultimate Penal Sanction (2d ed.)

Carolina Academic Press.

Blecker, Robert (forthcoming 2006). Encyclopedia of Civil Liberties, Entry on Retribution.

Blumenthal, Jeremy (2006). Implicit Theories and Capital Sentencing: An Experimental Study. Available on SSRN at http://papers.ssrn.com/sol3/papers.cfm?abstract_id=909603 Bohm, Robert M., Clarke, Louise J. and Aveni, Adrian F. (1990). The Influence of Knowledge on Reasons for Death Penalty Opinions: An Experimental Test. Justice Quarterly 7, 175-188.

Bright, Stephen B. and Keenan, Patrick J. (1995). Judges and the Politics of Death: Deciding Between the Bill of Rights and the Next Election in Capital Cases, Boston University 75, 759- 835.

Burke, Alafair S. (2006). Improving Prosecutorial Decision Making: Some Lessons of Cognitive Science. William and Mary Law Review 47, 1587-1633.

Carter, Linda E. and Kreitzberg, Ellen (2004). Understanding Capital Punishment Law. Newark, N.J.: LexisNexis.

Damasio, Antonio (1994). Descartes’ Error. Boston, MA: Norton. 
Dezhbakhsh, Hashem, Rubin Paul et. al. (2003). Does Capital Punishment Have a Deterrent Effect? New Evidence From Postmoratorium Panel Data, 5 Am. L. \& Econ. Rev. 344-376.

Donohue, John and Wolfers, Justin (2005). Uses and Abuses of Statistical Evidence in the Death Penalty Debate, Stanford Law Review 58, 791-846.

Dubber, Markus Dirk (2006). The Sense of Justice: Empathy in Law and Punishment. New York: New York University Press.

Durkheim, Emile (1984). The Division of Labor in Society, translated by W. D. Halls. New York: Free Press.

Dweck, Carol S. et al., Implicit Theories and Their Role in Judgments and Reactions: A World From Two Perspectives (1995). 6 Psychol. Inquiry 267-285.

Ehrlich, Isaac (1975). The Deterrent Effect of Capital Punishment: A Question of Life and Death. 65 Am. Econ. L. Rev. 347-417.

Ehrlich, Isaac (1977). Capital Punishment and Deterrence: Some Further Thoughts and Additional Evidence, 85 J. Polit. Econ. 741-88 (1977).

Ellsworth, Phoebe C. and Gross, Samuel R. (1994). Hardening of the Attitudes: Americans' Views on the Death Penalty. Journal of Social Issues 50, 19-52.

Ellsworth, Phoebe C. and Ross, Lee (1983). Public Opinion and Capital Punishment: A Close Examination of the Views of Abolitionists and Retentionists. Crime and Delinquency 29, 116-169.

Fagan, Jeffrey, Zimring, Frank E. and Geller, Amanda (2006). Capital Punishment and Capital Murder: Market Share and the Deterrent Effects of the Death Penalty. Available at http://ssrn.com/abstract=928649 
Feinberg, Joel J. (1970). ‘The Expressive Function of Punishment,' Doing and Deserving. Princeton: Princeton University Press.

Fisher, Gene A. and Chon, Kyum Koo (1989). Durkheim and the Social Construction of Emotions. Social Psychology Quarterly 52, 1-9.

Freedman, Monroe H. and Smith, Abbe (2004). Understanding Lawyers’ Ethics (3rd Ed.) Newark, N.J.:LexisNexis.

Garland, David (1990). Frameworks of Inquiry in the Sociology of Punishment. The British Journal of Sociology 41, 1-15.

Garland, David (2001). The Culture of Control: Crime and Social Order in Contemporary Society. Chicago: The University of Chicago Press.

Garland, David (2005). Capital Punishment and American Culture. Punishment and Society 7, 347-376.

Garvey, Stephen P., Johnson, Sheri Lynn and Marcus, Paul (2000). Correcting Deadly Confusion: Responding to Jury Inquiries in Capital Cases. Cornell Law Review 85, 627655.

Gerstein, Robert S. (1974). Capital Punishment-“Cruel and Unusual?”: A Retributivist Response, Ethics 85, 75-79.

Goodenough, Oliver R. and Prehn, Kristin (2004). A neuroscientific approach to normative judgment in law and justice. Phil. Trans. R. Soc. Lond. B 359, 1709-1726. Greene, J.D., Sommerville, R.B., Nystrom, L.E., Darley, J.M. \& Cohen, J.D. (2001). An fMRI investigation of emotional engagement in moral judgment. Science 293, 21052108. 
Greenhouse, Linda (2005). Becoming Justice Blackmun: Harry Blackmun’s Supreme Court Journey. New York: Times Books.

Gross, Samuel R. (1998). Update: American Public Opinion on the Death Penalty—It’s Getting Personal. Cornell Law Review 83, 1448-1462.

Haidt, Jonathan (2001). The Emotional Dog and Its Rational Tail: A Social Intuitionist Approach to Moral Judgment. Psychological Review 108, 814-834.

Haney, Craig (1997). Violence and the Capital Jury: Mechanisms of Moral

Disengagement and the Impulse to Condemn to Death. Stanford Law Review 49, 14471486.

Haney, Craig (2005). Death by Design: Capital Punishment as a Social Psychological System. New York: Oxford University Press.

Hart, H.L.A. (1968). Punishment and Responsibility: Essays in the Philosophy of Law. New York: Oxford University Press.

Hauser, Marc, Young, Liane and Cushman, Fiery (2006). Reviving Rawls’ Linguistic Analogy: Operative Principles and the Causal Structure of Moral Actions. Moral Psychology and Biology. W. Sinnott-Armstrong ed. New York: Oxford University Press. Henderson, Lynne N. (1985). The Wrongs of Victims’ Rights. Stanford Law Review 37, 937-

Kahan, Dan M. and Braman, Donald (2005). Cultural Cognition and Public Policy. Yale Law \& Policy Review 24, 147-169.

Kotlowitz, Alex, In the Face of Death. The New York Times Magazine, July 6, 2003. Kropf, Schuyler, Judge Discusses Death Penalty, The Charleston Post and Courier, September 15, 2006. 
Kunda, Ziva (1990). The Case for Motivated Reasoning. Psychological Bulletin 108, 480-498.

Kurzban, Robert, DeScioli, Peter and O’Brien, Erin (2006). Audience Effects on Moralistic Punishment. Available at http://www.psych.upenn.edu/PLEEP/pdfs/in press Kurzban DeScioli Obrien.pdf

Liebman, James S. (2000). The Overproduction of Death. Columbia Law Review 100, 2030-2156.

Liebman, James S., Gelman, Andrew, Davies, Garth, Fagan, Jeffrey, West, Valerie and Kiss, Alexander (2002). A Broken System: Part II: Why There is So Much Error in Capital Cases, and What Can be Done About It. Available at http://www.law.columbia.edu/brokensystem2/report.pdf

Lifton, Robert Jay and Mitchell, Greg (2002). Who Owns Death?: Capital Punishment, the American Conscience, and the End of Executions. New York: Harper Collins. Lipschultz, Jeremy H. and Hilt, Michael L. (2002). Crime and Local Television News: Dramatic, Breaking, and Live From the Scene. Mahwah, NJ: Lawrence Erlbaum Associates, Inc.

Lithwick, Dahlia, Does Killing Really Give Closure? Washington Post, March 26, 2006. Logan, Wayne (2006). Pathos and Punishment: The Use of Victim Impact Evidence in Mass Killing Prosecutions (draft manuscript, copy on file with author).

Lord, C.G., Ross, L. \& Lepper, M.R. (1979). Biased assimilation and attitude polarization: The effects of prior theories on subsequently considered evidence. Journal of Personality and Social Psychology 47. 2098-2109.

Markel, Dan (2004). Against Mercy. Minnesota Law Review 88, 1421-1480. 
Murphy, Jeffrie (1999). Moral Epistemology, the Retributive Emotions, and the "Clumsy Moral Philosophy” of Jesus Christ, In Susan Bandes (Ed.), The Passions of Law (pp. 149167). New York: New York University Press.

Murphy, Jeffrie and Hampton, Jean (1988). Forgiveness and Mercy. Cambridge: Cambridge University Press.

Murphy, Jeffrie (2006). Legal Moralism and Retribution Revisited. Presidential Address, American Philosophical Association, Pacific Division, delivered on March 24, 2006.

Nussbaum, Martha C. (2001). Upheavals of Thought: The Intelligence of Emotions. Cambridge: Cambridge University Press.

Osofsky, Michael J., Bandura, Albert and Zimbardo, Philip G. (2005). The Role of Moral Disengagement in the Execution Process. Law and Human Behavior 29, 371-393.

Owens, Erik C. and Elshtain, Eric P. (2004). Religion and Capital Punishment: An Introduction. In Erik C. Owens, John D. Carlson, and Eric P. Elshtain (Eds.), Religion and the Death Penalty: A Call for Reckoning (pp.1-22). Grand Rapids, Michigan: Wm B. Eerdsmans Publishing Co.

Radelet, Michael L. and Borg, Marian J. (2000). The Changing Nature of Death Penalty Debates. Annual Review of Sociology 26, 43-61.

Robinson, Paul and Kurzban, Robert (2006). Intuitions of Justice. U. of Pa. Law School, Public Law Working Paper No. 06-20. Available at http://ssrn.com/abstract=887958 Robinson, Paul H. (2006). Competing Conceptions of Modern Desert: Vengeful, Deontological, and Empirical. U of Penn Law School, Public Law Working Paper No. 06-32 Available at SSRN: http://ssrn.com/abstract=924917 
Sarat, Austin (2001). When the State Kills: Capital Punishment and the American

Condition. Princeton: Princeton University Press.

Shaw, Theodore M., Wrong on Wrongful Executions, The Washington Post, July 2, 2006.

Sigler, Mary (2000). The Story of Justice: Retribution, Mercy, and the Role of Emotions in the Capital Sentencing Process. Law and Philosophy 19, 339-367.

Steele, John (2001). A Seal Pressed in the Hot Wax of Vengeance: A Girardian

Understanding of Expressive Punishment. J. L. \& Religion 16, 35-68.

Steiner, Benjamin D., Bowers, William J. and Sarat, Austin (1999). Folk Knowledge as Legal Action: Death Penalty Judgments and the Tenet of Early Release in a Culture of Mistrust and Punitiveness. Law and Society Review 33, 461-505.

Streib, Victor L. (2005). Death Penalty in a Nutshell. St. Paul, Minn.: Thomson/West.

Sundby, Scott E. (2006). The Death Penalty's Future: Charting the Crosscurrents of

Declining Death Sentences and the McVeigh Factor. Texas Law Review 84, _-

(forthcoming) available at http://ssrn.com/abstract=909176.

Sundby, Scott E. (2005). A Life and Death Decision: A Jury Weighs the Death Penalty. New York: Palgrave MacMillan.

Sunstein, Cass R. (1996). On the Expressive Function of Law. U. Pa. Law Review 144, 2021-53.

Taslitz, Andrew E. (2005). Willfully Blinded: On Date Rape and Self-Deception, 28

Harv. J. L. \& Gender 28, 381-446.

Turner, Jonathan and Stets, Jan E. (2005).The Sociology of Emotions. New York:

Cambridge University Press. 
Turow, Scott (2003). To Kill or Not to Kill: Coming to Terms With Capital Punishment.

The New Yorker, January 6, 2003.

Tyler, Tom and Weber, Renee (1982). Support for the Death Penalty: Instrumental

Response to Crime, or Symbolic Attitude? Law \& Society Review 17, 21-44.

Bedantam, Shankar, How the Brain Helps Partisans Admit No Gray, Washington Post, July 31, 2006.

Weisberg, Robert (2005). The Death Penalty Meets Social Science: Deterrence and Jury Behavior Under New Scrutiny. The Annual Review of Law and Social Science 167-168.

Yen, Shih-Chen and Finkel, Leif H. (2002). Encyclopedia of the Human Brain Volume 4. Elsevier Science.

Whitman, James Q. (2003). Harsh Justice: Criminal Punishment and the Widening

Divide Between America and Europe. New York: Oxford University Press.

Zimring, Franklin E. (2003). The Contradictions of American Capital Punishment . New

York: Oxford University Press.

\section{Cases Cited}

California v. Brown, 479 U.S. 538 (1986).

Callins v. Collins, 510 U.S. 1141 (1994) (cert. denied) (Blackmun, J., dissenting).

Furman v. Georgia, 408 U.S. 238 (1972).

Herrara v. Collins, 506 U.S. 390 (1993).

Schlup v. Delo, 513 U.S. 298 (1995).

Bell v. House, 539 U.S. 937 (2003).

Republican Party of Minnesota v. White, 536 U.S. 765 (2002). 
Readers with comments should address them to:

Professor Susan Bandes

University of Chicago Law School

1111 East 60th Street

Chicago, IL 60637

sbandes@uchicago.edu 


\section{Chicago Working Papers in Law and Economics (Second Series)}

For a listing of papers 1-299 please go to Working Papers at http://www.law.uchicago.edu/Lawecon/index.html

300. Adam B. Cox, The Temporal Dimension of Voting Rights (July 2006)

301. Adam B. Cox, Designing Redistricting Institutions (July 2006)

302. Cass R. Sunstein, Montreal vs. Kyoto: A Tale of Two Protocols (August 2006)

303. Kenneth W. Dam, Legal Institutions, Legal Origins, and Governance (August 2006)

304. Anup Malani and Eric A. Posner, The Case for For-Profit Charities (September 2006)

305. Douglas Lichtman, Irreparable Benefits (September 2006)

306. M. Todd Henderson, Paying CEOs in Bankruptcy: Executive Compensation when Agency Costs Are Low (September 2006)

307. Michael Abramowicz and M. Todd Henderson, Prediction Markets for Corporate Governance (September 2006)

308. Randal C. Picker, Who Should Regulate Entry into IPTV and Municipal Wireless? (September 2006)

309. Eric A. Posner and Adrian Vermeule, The Credible Executive (September 2006)

310. David Gilo and Ariel Porat, The Unconventional Uses of Transaction Costs (October 2006)

311. Randal C. Picker, Review of Hovenkamp, The Antitrust Enterprise: Principle and Execution (October 2006)

312. Dennis W. Carlton and Randal C. Picker, Antitrust and Regulation (October 2006)

313. Robert Cooter and Ariel Porat, Liability Externalities and Mandatory Choices: Should Doctors Pay Less? (November 2006)

314. Adam B. Cox and Eric A. Posner, The Second-Order Structure of Immigration Law (November 2006)

315. Lior J. Strahilevitz, Wealth without Markets? (November 2006)

316. Ariel Porat, Offsetting Risks (November 2006)

317. Bernard E. Harcourt and Jens Ludwig, Reefer Madness: Broken Windows Policing and Misdemeanor Marijuana Arrests in New York City, 1989-2000 (December 2006)

318. Bernard E. Harcourt, Embracing Chance: Post-Modern Meditations on Punishment (December 2006)

319. Cass R. Sunstein, Second-Order Perfectionism (December 2006)

320. William M. Landes and Richard A. Posner, The Economics of Presidential Pardons and Commutations (January 2007)

321. Cass R. Sunstein, Deliberating Groups versus Prediction Markets (or Hayek’s Challenge to Habermas) (January 2007)

322. Cass R. Sunstein, Completely Theorized Agreements in Constitutional Law (January 2007)

323. Albert H. Choi and Eric A. Posner, A Critique of the Odious Debt Doctrine (January 2007)

324. Wayne Hsiung and Cass R. Sunstein, Climate Change and Animals (January 2007)

325. Cass. R. Sunstein, Cost-Benefit Analysis without Analyzing Costs or Benefits: Reasonable Accommodation, Balancing and Stigmatic Harms (January 2007)

326. Cass R. Sunstein, Willingness to Pay versus Welfare (January 2007)

327. David A. Weisbach, The Irreducible Complexity of Firm-Level Income Taxes: Theory and Doctrine in the Corporate Tax (January 2007)

328. Randal C. Picker, Of Pirates and Puffy Shirts: A Comments on "The Piracy Paradox: Innovation and Intellectual Property in Fashion Design” (January 2007)

329. Eric A. Posner, Climate Change and International Human Rights Litigation: A Critical Appraisal (January 2007)

330. Randal C. Picker, Pulling a Rabbi Out of His Hat: The Bankruptcy Magic of Dick Posner (February 2007)

331. Bernard E. Harcourt, Judge Richard Posner on Civil Liberties: Pragmatic (Libertarian) Authoritarian (February 2007) 
332. Cass R. Sunstein, If People Would Be Outraged by Their Rulings, Should Judges Care? (February 2007)

333. Eugene Kontorovich, What Standing Is Good For (March 2007)

334. Eugene Kontorovich, Inefficient Customs in International Law (March 2007)

335. Bernard E. Harcourt, From the Asylum to the Prison: Rethinking the Incarceration Revolution. Part II: State Level Analysis (March 2007)

336. Cass R. Sunstein, Due Process Traditionalism (March 2007)

337. Adam B. Cox and Thomas J. Miles, Judging the Voting Rights Act (March 2007)

338. M. Todd Henderson, Deconstructing Duff \& Phelps (March 2007)

339. Douglas G. Baird and Robert K. Rasmussen, The Prime Directive (April 2007)

340. $\quad$ Cass R. Sunstein, Illusory Losses (May 2007)

341. Anup Malani, Valuing Laws as Local Amenities (June 2007)

342. David A. Weisbach, What Does Happiness Research Tell Us about Taxation? (June 2007)

343. David S. Abrams and Chris Rohlfs, Optimal Bail and the Value of Freedom: Evidence from the Philadelphia Bail Experiment (June 2007)

344. Christopher R. Berry and Jacob E. Gersen, The Fiscal Consequences of Electoral Institutions (June 2007)

345. Matthew Adler and Eric A. Posners, Happiness Research and Cost-Benefit Analysis (July 2007)

346. Daniel Kahneman and Cass R. Sunstein, Indignation: Psychology, Politics, Law (July 2007)

347. Jacob E. Gersen and Eric A. Posner, Timing Rules and Legal Institutions (July 2007)

348. $\quad$ Eric A. Posner and Adrian Vermeule, Constitutional Showdowns (July 2007)

349. Lior Jacob Strahilevitz, Privacy versus Antidiscrimination (July 2007)

350. Bernard E. Harcourt, A Reader's Companion to Against Prediction: A Reply to Ariela Gross, Yoram Margalioth, and Yoav Sapir on Economic Modeling, Selective Incapacitation, Governmentality, and Race (July 2007)

351. Lior Jacob Strahilevitz, “Don’t Try This at Home”: Posner as Political Economist (July 2007)

352. Cass R. Sunstein, The Complex Climate Change Incentives of China and the United States (August 2007)

353. David S. Abrams and Marianne Bertrand, Do Judges Vary in Their Treatment of Race? (August 2007)

354. Eric A. Posner and Cass R. Sunstein, Climate Change Justice (August 2007)

355. David A. Weisbach, A Welfarist Approach to Disabilities (August 2007)

356. David S. Abrams, More Time, Less Crime? Estimating the Deterrent Effect of Incarceration using Sentencing Enhancements (August 2007)

357. Stephen J. Choi, G. Mitu Gulati and Eric A. Posner, Professionals or Politicians: The Uncertain Empirical Case for an Elected Rather than Appointed Judiciary (August 2007)

358. Joseph Bankman and David A. Weisbach, Consuption Taxation Is Still Superior to Income Taxation (September 2007)

359. Dougals G. Baird and M. Todd Henderson, Other People’s Money (September 2007)

360. William Meadow and Cass R. Sunstein, Causation in Tort: General Populations vs. Individual Cases (September 2007)

361. Richard McAdams and Janice Nadler, Coordinating in the Shadow of the Law: Two Contextualized Tests of the Focal Point Theory of Legal Compliance (September 2007)

362. Richard McAdams, Reforming Entrapment Doctrine in United States v. Hollingsworth (September 2007)

363. M. Todd Henderson, From Seriatim to Consensus and Back Again: A Theory of Dissent (October 2007)

364. Timur Kuran and Cass R. Sunstein, Availability Cascades and Risk Regulation (October 2007)

365. David A. Weisbach, The Taxation of Carried Interests in Private Equity (October 2007)

366. $\quad$ Lee Anne Fennell, Homeownership 2.0 (October 2007)

367. Jonathan R. Nash and Rafael I. Pardo, An Empirical Investigation into Appellate Structure and the Perceived Quality of Appellate Review (October 2007)

368. Thomas J. Miles and Cass R. Sunstein, The Real World of Arbitrariness Review (November 2007)

369. Anup Malani, Maciej F. Boni, Abraham Wickelgren, and Ramanan Laxminarayan, Controlling Avian Influenza in Chickens (November 2007)

370. Richard H. McAdams, The Economic Costs of Inequality (November 2007) 
371. Lior Jacob Strahilevitz, Reputation Nation: Law in an Era of Ubiquitous Personal Information (November 2007)

372. Thomas J. Miles and Cass R. Sunstein, The New Legal Realism (December 2007)

373. M. Todd Henderson, Everything Old Is New Again: Lessons from Dodge V. Ford Motor Company (December 2007)

374. Jonathan Remy Nash, Economic Efficiency versus Public Choice: The Case of Property Rights in Road Traffic (December 2007)

375. Edward L. Glaeser and Cass R. Sunstein, Extremism and Social Learning (December 2007)

376. Stephen J. Choi, G. Mitu Gulati, and Eric A. Posner, Are Judges Overpaid?: A Skeptical Response to the Judicial Salary Debate (December 2007)

377. Eric A. Posner, Does Political Bias in the Judiciary Matter?: Implicatoins of Judicial Bias Studies for Legal and Constitutional Reform (January 2008)

378. Susan Bandes, The Heart Has Its Reasons: Examining the Strange Persistence of the American Death Penalty (January 2008) 